\title{
APPLYING DATA ENVELOPMENT ANALYSIS TO OPERATING PERFORMANCE IN TEXTILE INDUSTRY
}

\author{
Chia-Hui Ho
}

Department of Tourism Management, Far East University, Taiwan, ROC

E-mail: chia@cc.feu.edu.tw

\begin{abstract}
:
Operating performance could affect the survival and future development of a business that both businesses and business managers would devote to the enhancement of operating performance. Having developed for more than four decades, the consistent upstream, mid-stream and downstream system have been constructed in domestic textile industry. The output value of textiles in Taiwan has exceeded 480 billion NT dollars, which is not a sunset industry, as generally described. The impacts of high labour cost, environmental protection measures and changes of capital market as well as the competition of emerging countries, particularly Mainland China, have made textile industry in Taiwan face great market competition and pressure. Since textiles are regarded as one of the major products in Taiwan, the operating performance could affect the survival of the overall industry. In this case, operating performance survey of textile manufacturers in Taiwan during 2010-2012 is combined with Data Envelopment Analysis and Slack Variable Analysis to measure the total efficiency, pure technical efficiency and scale efficiency of top 12 textile manufacturers in Taiwan, tending to provide the reference of operating efficiency improvement for the manufacturers.

The empirical results show that the overall efficiency in the 3 years appears 0.89 averagely. The relative efficiency (1) between two manufacturers, Far Eastern New Century and Ruentex Industries, achieves the optimal operating efficiency, whereas the remaining 10 are comparatively worse. Regarding the analysis of returns to scale, two textile manufacturers present constant returns to scale, with the optimal operating efficiency, whereas the remaining 10 show increasing returns to scale, revealing that expanding the scale could enhance the marginal return and further promote the efficiency.
\end{abstract}

\section{Keywords:}

Textile industry, traditional industries, Data Envelopment Analysis, operating performance

\section{Research background}

Textile industry in Taiwan runs well with low wages and industrious labours. The imported natural and synthetic fibres were used for cloth and garments and then exported. The increased production of synthetic fibres, such as nylon and polyester, in the early 1980 and the development of midstream and downstream industries, like woven cloth, dyeing and finishing, have made synthetic fibre industry play a critical role in the continuous development of textile industry in Taiwan. Furthermore, as the area of Taiwan is not suitable for the development of natural fibres and the upstream industry, petrochemical industry, being capable of purchasing the most advanced chemical fibre equipment had made Taiwan the top chemical fibre country in the world, after the expansion for 20 years.

Textile industry presents great contribution on the overall economy, national employment, foreign currency creation and enhancement of peripheral industries. The impact of textile industry moving to Mainland China has induced Taiwanese manufacturers to produce mass-specification products in Mainland China but retain few high value-added products and the research \& development. It indirectly results in the output value of textile industry in Taiwan not being largely increased. Instead, the output value and the value of exports of textile industry in Mainland China increase because of the open market and the investment of foreign capitals. Complex correlations appear among industries. Although traditional industries present declination, high profits could still be generated by cooperating with other industries; even hi-tech products contain some parts produced by traditional industries.

According to Value of Exports and Imports, half of fibre, yarn, cloth and garments exported to Hong Kong are trans-shipped to Mainland China. Nevertheless, the growth rate of fibre, yarn, cloth and haberdashery, except garments, is declining, in which fibre declines up to $50 \%$. It is possibly because of the increasing capacity of chemical fibres in China and the enhancement of product self-efficiency so that the export amount of polyester fibres to China is reduced. The large-scale investment of textile industry used to have Taiwan as the area with the lowest production cost of global textile. However, the over-production also cause the manufacturers encounter the dilemma of "production is losing money". In face of the hard investment environments in Taiwan, textile industry has actively looked for new overseas locations in the past years, including Mainland China, Vietnam, Southeast Asia and Central America. The complete upstream, mid-stream and downstream textile system also show structural changes. Textile industry in Taiwan 
is developing hi-tech and high value-added textiles. In addition to making efforts to the differentiation of technology and design, textile businesses focus on the global market. This study is expected to provide the analysis results of textile businesses with better Operating Performance for the operation reflection of textile managers.

\section{Literature review}

\section{Measurement of operating performance}

Governmental policies, international economy, exchange rate, staff quality, investment strategy and interests are the common factors in business operating performance. For instance, export-oriented industries likely affect the operating performance by international economy, exchange rate and governmental policies. The decreasing exports could reduce industrial profits during unfavourably international economy; and, the decreasing export competitiveness because of domestic revaluation could also reduce industrial profits. Apparently, both internal and external factors could affect the operation status and the operating performance of individual manufacturer that the related variables should be considered in the research. Kuo [1] pointed out the business performance as the performance of operating activities, whereas the operating activities contained the creation of operating revenue, the control of cost and expense and the presentation of profit result.

Venkartraman and Ramanujam [2] judged organisational performance from financial, business and organisational performance. (1) Financial performance, the most common measuring index and definite method, contained sales growth rate and returns. (2) In addition to financial performance, business performance included operating performance that was analysed by measuring non-financial indices, like market share and product quality. (3) Organisational performance applied wider definitions. In addition to the above two, the achievement of organisational objectives and the target satisfaction of various parities were covered. Robbins [3] indicated that businesses often used financial performance and marketing performance for presenting the operating performance, including return on investment, return on sales, before-tax net profit, sales amount and sales growth rate in financial performance and market share in marketing. Van de Ven and Ferry [4] pointed out traditional financial performance of return on investment, sales revenue and profitability as the common indices for measuring organisational operation. Dess and Robinson [5] considered return on assets and sales growth rate as the commonly used financial indices.

Wu [6] proposed to measure business performance from the dimensions of intangible performance (business image, brand awareness, business information ability and goal achievement), productivity (employee productivity, capacity utilisation, product defect rate), profitability (return on investment and return on assets) and growth force (growth rate of market share, revenue growth rate) of a business. Chang [7] found the significantly positive effects of a parent company's investment experiences in China, investment scale and business scale on the performance that the higher investment experiences and the scale of the parent company, the better business Operating Performance. It was further indicated that no absolute correlation appeared between investing location and performance.

Robbins [3] developed the organisational performance index to evaluate organisational performance with eight criteria.

1. Productivity/efficiency, including output amount, output and input ratio.

2. Planning and target setting, stressing on the planning, target setting and evaluation process.

3. Resource acquisition, referring to the ability to acquire resources and external support.

4. Flexible/keen response, indicating external responses and the flexibility to continuously maintain the balance.

5. Stability/control, referring to the internal regulation and continuously maintaining the balance stability.

6. Information management/communication, indicating the sufficiency of information channels and the appropriateness of internal communication.

7. Emphasis of human resource/training, tending to enhance the staff competence and retain the talents.

8. Cohesiveness/morale, presenting the coordination among members.

\section{Operating performance in textile industry}

Based on the financial statements of 41 listing textile manufacturers in Taiwan, Kuo [8] selected 28 financial ratios for the questionnaire survey and interviews with business managers and researchers in order to acquire the information for operating performance evaluation and complete the evaluation. Totally, seven factors were selected, including profitability factor, financial structure and asset performance, debt-paying ability, sales efficiency, asset structure, inventory management ability and growth ability. Chang [7] studied listing textile manufacturers with factor analysis to extract the evaluation criteria (common factor) of revenue, safety, operation and asset utilisation. Chen [9] studied 50 listing textile manufacturers by collecting the financial data. Twentyfive financial ratios were used as the research variables for selecting the factors in Operating Performance, namely profitability, operating ability and constant asset growth.

The past research on Operating Performance in textile industry focused on listing manufacturers and the financial information, applied factor analysis to extract the principal elements and discriminated the performance of the research subjects clustered by such elements. The common problems appeared on the neglect of performance, which was not merely the revenue but also the operating efficiency. Consequently, Data Envelopment Analysis (DEA) is used for the performance 
evaluation in this study, expecting to compensate the insufficiency of past research with efficiency analysis. Kang and Liao [10] pointed out the indices for measuring business returns, including returns, growth rate, turnover rate, liquidity ratio and risk diversification ability, where the higher returns, growth rate, turnover rate and liquidity ratio presented the better operating performance, while the less risk was better. Chen [11] used earnings per share, sales growth rate and profit margin for measuring performance. Ma [12] evaluated operating performance of hi-tech industries with revenue, stability and business capacity, and the major evaluation indices focused on profitability, productivity and management performance, including operating profit ratio, net profit margin, liability ratio, total asset turnover rate and employee productivity.

\section{Research design}

Applying DEA to measuring operating performance of decisionmaking units (DMUs) in textile industry requires proper inputs and outputs. Fuzzy Delphi method is used for screening inputs and outputs to combine expert opinions, reduce input costs and avoid fuzziness in the interview. A total of 20 copies of questionnaire are distributed and 18 valid ones are retrieved, with the retrieval rate of $90 \%$. Fremont et al. [13] indicated that public opinions of more than five participants could be the analysis bases. The interviewed experts cover the industry, the official and the academia, and present frequent interaction with textile industry that they reveal certain representative.

With fuzzy Delphi method, the geometric mean is used as the experts' common consensus of inputs and outputs, and the evaluation score of such inputs/outputs is taken as the standard for selecting inputs/outputs to measure the operating performance in textile industry. Totally, four input/output variables are contained and, with strict selection, a total of nine DMUs are available.

Variable data are acquired from the issued prospectus and annual reports of the businesses.
Definition of the variable:

\section{Input variable:}

1. Number of employee indicates the sum of employees, containing management personnel, R\&D personnel, sales personnel and manufacturing personnel.

2. Operating cost refers to personnel expense, affair expense, maintenance expense, material expense and other expenses for the operation.

3. Total fixed assets are the total amount of land cost, buildings and construction cost, machine and machinery equipment cost, other equipment cost, construction in progress and advance payment, revaluation of assets and accumulated depreciation on the balance sheet, where fixed assets refer to the equipments for the operation, not for sales.

\section{Output variable:}

1. Operating revenue indicates sales or labour income in a period of time, including sales revenue, labour income, business income and other operating revenue.

\section{Empirical analysis of operating efficiency in}

\section{textile industry}

\section{Analysis of operating performance efficiency in textile industry}

The DEA efficiency evaluation results could assist in understanding the relative efficiency of operating performance among textile manufacturers. When the efficiency is 1 , the DMU achieves the relative efficiency; otherwise, the DMU is relatively insufficient when the efficiency is $<1$. The empirical results, Table 1, showed that two textile manufacturers, Far

Table 1. Relative efficiency of manufacturers in textile industry.

\begin{tabular}{|c|c|c|c|}
\hline Manufacturers in textile industry & Overall efficiency & Pure technical efficiency & Scale efficiency \\
\hline Formosa Taffeta & 0.92 & 0.95 & 0.93 \\
\hline Ruentex Industries & 1.00 & 1.00 & 1.00 \\
\hline Gsharp Corporation & 0.86 & 0.84 & 0.83 \\
\hline Li Peng Enterprises & 0.83 & 0.82 & 0.81 \\
\hline Far Eastern New Century & 1.00 & 1.00 & 1.00 \\
\hline Chung Shing Textile & 0.85 & 0.80 & 0.81 \\
\hline Everest Textile & 0.88 & 0.86 & 0.85 \\
\hline Tainan Enterprises & 0.94 & 0.88 & 0.89 \\
\hline Lealea Group & 0.90 & 0.89 & 0.90 \\
\hline Zig Sheng Industrial & 0.80 & 0.75 & 0.78 \\
\hline Nien Hsing Textile & 0.74 & 0.71 & 0.72 \\
\hline Chia Her Industrial & 0.76 & 0.72 & 0.74 \\
\hline
\end{tabular}


Eastern New Century and Ruentex Industries, were relatively efficient, with the efficiency 1 , revealing the operating efficiency achieving the optimal. The remaining 10 textile manufacturers, on the other hand, presented relatively worse operating efficiency.

\section{Slack variable analysis}

Regarding the analysis of returns to scale, Table 2, two textile manufacturers with constant returns to scale showed the optimal operating efficiency, whereas the remaining 10 appeared decreasing returns to scale, revealing that expanding the scale could enhance the marginal return and further promote the efficiency.

With regard to slack variable analysis, the improvement of abundant inputs is shown in Table 2 for the textile manufacturers. Such manufacturers could achieve efficient operation by reducing the inputs. Moreover, two textile manufacturers with operating efficiency presented the optimal input resources.

\section{Conclusion and suggestion}

The efficiency and the variables acquired from DEA are classified in Table 2. Two DMUs in textile industry show the strong operating efficiency (efficiency $=1$ ), about $17 \%$ of all DMUs, presenting the favorably relative operating efficiency. Three DMUs appear marginal insufficient (operating efficiency between 0.9 and 1 ), about $25 \%$ of all DMUs showing the possibility of enhancing the relative operating efficiency. Seven DMUs reveal obviously insufficient (operating efficiency <0.9), about $58 \%$ of all DMUs, in which Nien Hsing Textile appears the lowest operating efficiency 0.74 . Textile industry is the primary in the overall economic weight of Taiwan and presents enormous contribution. Textile businesses, therefore, should refer to the financial performance of the similar businesses with high performance as the objective. The DEA evaluation results show the favorable operating performance of Far Eastern New Century. To cope with global distribution and develop the comprehensive effectiveness, Far Eastern Group establishes two operation head offices: chemical fibre operation head office and textile operation head office. The former, crossing the strait with the polyester production weight $1: 1$, presents the total output value up to 1.6 million tons and becomes the top five polyester manufacturers in the world. In face of the excess supply of polyester globally, Far Eastern New Century presents the core competitiveness of special specification and high value-added products with the advanced technology.

In global textile market, the prices are continuously dropping and the product life cycle is shortening; in such a low-profit era, textiles are mostly supplied by developing countries with the advantage of low costs, whereas developed countries are developing functional and industrial textiles with high value added. Far Eastern New Century has focused on the research and development of cross-cutting products of smart textiles and medical textiles through hi-tech. With the concerns of environmental protection and energy price, low-pollution and low-energy processing technology and products have become one of the key developments in textile industry. With regard to processing technology, technology has been applied to textiles through the integration of production systems with cross-cutting technology of material technology, biotechnology, and nanotechnology and the meshing. Green textiles derived from processing technology present the products with green materials, energy safe and waste reduction, and reuse. International brands, like NIKE, starts to utilise recycled materials for the increasing demands on green fibres. There are several textile businesses in Taiwan investing in the development of green materials. For instance, plastic bottles are recycled to reconstruct usable fibres and distinct textiles for home decoration, clothing and industries. The future improvement of processing technology and products could have textile industry become more efficient and save energy, or better correspond to the environmental standards.

Table 2. Improvement of manufacturers in textile industry.

\begin{tabular}{|c|c|c|c|c|c|}
\hline \multirow{2}{*}{ Decision-making unit (DMU) } & \multicolumn{3}{|c|}{ Improvement of input } & \multirow{2}{*}{$\begin{array}{c}\text { Improvement } \\
\text { of output } \\
\begin{array}{c}\text { Operating } \\
\text { revenue }\end{array}\end{array}$} & \multirow[t]{2}{*}{$\begin{array}{l}\text { Returns } \\
\text { to scale }\end{array}$} \\
\hline & $\begin{array}{l}\text { Number of } \\
\text { employee }\end{array}$ & $\begin{array}{l}\text { Operating } \\
\text { cost }\end{array}$ & $\begin{array}{l}\text { Total fixed } \\
\text { assets }\end{array}$ & & \\
\hline Formosa Taffeta & 1 & 2 & 0 & 0 & IRS \\
\hline Ruentex Industries & 0 & 0 & 0 & 0 & CRS \\
\hline Gsharp Corporation & 0 & 3 & 4 & 4 & IRS \\
\hline Li Peng Enterprises & 0 & 0 & 2 & 7 & IRS \\
\hline Far Eastern New Century & 0 & 0 & 0 & 0 & CRS \\
\hline Chung Shing Textile & 3 & 0 & 5 & 2 & IRS \\
\hline Everest Textile & 0 & 5 & 1 & 0 & IRS \\
\hline Tainan Enterprises & 1 & 1 & 1 & 6 & IRS \\
\hline Lealea Group & 2 & 0 & 3 & 5 & IRS \\
\hline Zig Sheng Industrial & 0 & 0 & 5 & 5 & IRS \\
\hline Nien Hsing Textile & 2 & 2 & 3 & 8 & IRS \\
\hline Chia Her Industrial & 0 & 4 & 0 & 10 & IRS \\
\hline
\end{tabular}

Data source: Organised in this study. 


\section{Reference}

[1] Kuo, Min-hua., Business Analysis and Valuation (written by K.G. Palepu, P.M. Healy, V.L. Bernard, Erik Peek, IFRS edition). Thomson, translated 2009.

[2] Venkartraman, N., Ramanujan, V., Measurement of business performance in strategy research: a comparison of approaches. Academy of Management Review, 1986, 11(4), 801-815.

[3] Robbins, S.P., Organizational Behavior. 2001.

[4] Van De Ven, A.H., Ferry, D.L., Measuring and Assessing Organizations. New York: John Wiley \& Sons, 1980.

[5] Dess, G.C., Robinson, R.B., Measuring organizational performance in the absence of objective measures. Strategic Management Journal, 1984, 5(3): 265-273.

[6] Wu, Wan-yi, Taiwanese firms' investment strategy and operating performance in China and Southeast Asia. Fu Jen Management Review, 2010, 1: 51-75.

[7] Chang, Kuo-shien, The assessment of performance on listed companies of textiles in Taiwan. Chiao Da Journal of Management, 2011, 139-168.
[8] Kuo, Chun-han, Business operating performance evaluation - case study on domestic listing companies in textile industry. Journal of Management, 2010, 19(5), 811842.

[9] Chen, Chin-chun, Business operating performance evaluation model - a case study on listing companies in Taiwan. Journal of Management, 2010, 15(3): 393-418.

[10] Kang, Hsin-hong, Liao, Kuang-chiang, A study on the feasibility of the application of "portfolio model" on the strategy of diversification in direct investment. NTU Management Review, 2009, 171-197.

[11] Chen, Kuo-chia, Strategic groups, mobility barriers, and performance: empirical research. Taiwan Economics, 2009, 45-61.

[12] Ma, Wei-yang, An empirical study on hi-tech industrial development in Taiwan. Journal of Technology Management, 2010, 4(2), 57-71.

[13] Fremont, A.S., Jr., Delbecg, A.L., Curmings, L.L., Organizational Decision Making. McGraw-Hill, 1970, p. 151.

[14] Chnag, Chia-er, An empirical study of the investment strategy and performance in Mainland China - the case of Taiwan Information and Electronic Firms' Investment. Journal of Management Science, 2011, 12(2): 153-168. 